\title{
Koop's corps of biomedical workers cured with kindness
}

\section{Washington}

Political struggles within the US Department of Health and Human Services (HHS) may soon yield a surprise reward for biomedical researchers working at such laboratories as the National Institutes of Health (NIH). An HHS plan for a new "senior biomedical research service" would raise top salaries to $\$ 110,000$ a year, making scientists better off than senior government officials, including even cabinet secretaries.

According to HHS officials a rise is needed to stem the drain of top researchers out of their laboratories and into the universities and industry. Clinical department chairmen in medical schools now average $\$ 167,000$ a year, almost double the top pay of $\$ 85,000$ a year at NIH. But the existence of the salary gap does not completely explain HHS's interest in a new research service; it may have much to do with a separate issue, the wish of Surgeon General C. Everett Koop to revitalize the Public Health Service Commissioned Officers Corps.

The corps is no longer a highly visible body and many of its functions have passed into history (see right). Over the past twenty years it has often been under threat of abolition even though the Surgeon General, the corps' chief officer, has traditionally functioned as an outspoken guardian of the nation's health.

Koop is no exception to the role and has weighed in with controversial pronouncements on AIDS. He also proudly wears the corps' uniform and has announced his determination to revitalize its spirit. Unless a major role is found for the corps, he says,"we would see its demise within a decade". Koop's solution stresses the military spirit of the corps, "expert, flexible and mobile; our only defence against nonmilitary disaster". As examples of what the corps can do, he cites the emergency work carried out when Cuban refugees arrived in Miami and recent postings to drought-stricken regions of the Sudan.

The corps, as Koop freely admits, is less than mobile and has far too many officers in the upper ranks. But not all his first efforts to bring change have been welcome. Attempts to make staff retire after 30 years' service were virtually abandoned after NIH pointed out that some of the most productive research groups would thus be left leaderless. But uniforms are once more being worn.

Opposition to Koop's revitalization

\section{Correction}

The director of the MacArthur Center for Tropical and Parasitic Diseases at the Weizmann Institute in Israel (see Nature 327, 581; 1987) is Professor Ruth Arnon. plans is strong among senior members of the corps, many of whom joined during the Vietnam war when service offered an alternative to a spell in the army. The pay plan may provide a way around them. At present, corps members are often better paid than civil servants in the same laboratory, with top salaries around the $\$ 100,000$ mark. But under the new scheme the same researchers would be better off if they transferred out of the corps - leaving Koop with those who are willing to go along with his ideas

Whether the scheme will overcome opposition from those anxious to reduce the cost of government remains to be seen. If it is successful it could help both to revitalize the Commissioned Corps, and stop the brain drain from NIH. But it will leave less senior biomedical researchers wondering why they too cannot enjoy salaries of the kind they hear about in universities and industry. Alun Anderson Most of the Commissioned Corps' 5,364 members work at the Health Resources and Services Administration, but a large contingent is also found doing research at NIH, where one of its best-known officers is AIDS researcher Robert Gallo. A walk down NIH's corridors would not, however, reveal who is a commissioned officer and who an ordinary civil service employee but in law largely forgotten differences exist.

The Commissioned Corps was created in 1889 when Congress turned the Marine Hospital Service into a military organization with titles and pay corresponding to Army and Navy ranks. Today, the corps is still one of the uniformed services of the United States, alongside Army, Navy, Air Force, Marines and the Coastguard; in time of war or national emergency, the president can designate it a full military service. Rarely applied military-style regulations still exist: its officers can be rotated to new commands at short notice, be required to stand down after $\mathbf{3 0}$ years' service, and be required to wear their Navystyle uniforms.

The corps' heyday came perhaps earlier this century when the rapid deployment of skilled health workers was essential to prevent epidemics. In the corps' own manuals, the military spirit still lives on: the officers are soldiers and "in the silent war against disease, there is no truce - no retreat - no peace. The unrelenting battle goes on against the deadly enemy ... . it stalks the world wantonly crippling and killing millions."

Modern functions of the corps include providing health care for native Americans and for isolated communities. But these are perhaps its only unique functions.

\section{NET succeeds JET}

The European Commission has committed part of its newly-agreed research budget to the construction of the Next European Torus (NET), the successor to JET (Joint European Torus), the research-level machine now operating successfully at Culham in Oxfordshire, Britain, which is also the site of the UK Atomic Energy Authority's thermonuclear fusion laboratory. In total, the commission has allocated ECU 911 million (about $£ 700$ million) for NET, on which construction would begin only in the 1990s. The budget is expected formally to be agreed this week at a meeting of Community finance ministers, but decisions about the siting of the enterprise will be made only at a later date. Culham has been mentioned as a suitable location, but West Germany is also a strong contender.

K.J.

\section{Science council change}

The British Science and Engineering Council (SERC) is to be reorganized in a way that will give its chairman more influence. After the retirement of the present secretary to SERC, Ashley Catterall, next year, the post will be reduced in importance. The present chairman, Professor W. J. Mitchell on a five-year secondment from the University of Oxford, plans a tricha of administrators one (the head of the Rutherford-Appleton Laboratory) dealing with research laboratories, another (Dr Harry Atkinson) channelling the opinions of the four research boards to the chairman and yet another administering grant applications and SERC housekeeping.

\section{Tenure to go in Britain}

Against expectations, the Secretary of State for Education and Science in the British government, Mr Kenneth Baker, has decided to include the abolition of academic tenure in his forthcoming education bill to be published in the autumn. The proposal is certain to be controversial: earlier this week, a spokesman for the Committee of Vice-Chancellors and Principals asked whether [this] is "to cut costs or to cut dissent". Ms Diana Warwick, secretary-general of the Association of University Teachers, says that the objective must be to make universities contract more quickly. Academic tenure features in the standard contracts of employment of only 23 out of 47 universities in Britain, many of which are considering whether their royal charters should be changed. The government's proposals would apply only to newly appointed academics and to those changing institutions, but a novel feature is that a person's "inefficiency" is added to the list of "good causes" for which a person may be dismissed, of which the chief is the institution's inability to pay his/ her salary. 